\title{
Detection of EGFR mutations in circulating free DNA by PNA-mediated PCR clamping
}

Hye-Ryoun Kim², Sung Yong Lee ${ }^{2}$, Dae-Sung Hyun ${ }^{3}$, Min Ki Lee ${ }^{4}$, Hyun-Kyung Lee ${ }^{5}$, Chang-Min Choi ${ }^{6}$, Sei-Hoon Yang ${ }^{7}$, Young-Chul Kim ${ }^{8}$, Yong Chul Lee ${ }^{9}$, Sun Young Kim ${ }^{10}$, Seung Hun Jang ${ }^{11}$, Jae Cheol Lee ${ }^{6^{*}+}$ and Kye Young Lee L2*t $^{*}$

\begin{abstract}
Background: Epidermal growth factor receptor (EGFR)-activating mutations are major determinants in predicting the tumor response to EGFR tyrosine kinase inhibitors in non-small cell lung cancer (NSCLC). Noninvasive test for the detection of EGFR mutations is required, especially in NSCLC patients from whom tissue is not available. In this study, we assessed the feasibility of detection of EGFR mutations in free DNA circulating in plasma.

Methods: Plasma samples of 60 patients with partial response to gefitinib were analyzed to detect EGFR-activating mutations in exons 19 and 21. Forty (66.7\%) of patients had tumor EGFR mutation results. EGFR mutations in plasma were detected using the peptide nucleic acid (PNA)-mediated polymerase chain reaction (PCR) clamping method. All clinical data and plasma samples were obtained from 11 centers of the Korean Molecular Lung Cancer Group (KMLCG).

Results: Of the 60 patients, 39 were female and the median age was 62.5 years. Forty-three patients never smoked, 53 had adenocarcinomas, and seven had other histologic types. EGFR-activating mutation was detected in plasma of 10 cases (exon 19 deletion in seven and exon 21 L858R point mutation in three). It could not be found in plasma after treatment for 2 months. When only patients with confirmed EGFR mutation in tumor were analyzed, 17\% (6 of 35) of them showed positive plasma EGFR mutation and the mutation type was completely matched with that in tumor. There was no statistically significant difference in clinical parameters between patients with EGFR mutations in plasma and those without EGFR mutations.

Conclusions: The detection rate of EGFR mutations from plasma was not so high despite highly sensitive EGFR mutation test suggesting that more advances in detection methods and further exploration of characteristics of circulating free DNA are required.
\end{abstract}

Keywords: Plasma, EGFR mutation, PNA-mediated PCR clamping method, Non-small cell lung cancer

\section{Background}

Epidermal growth factor receptor (EGFR) mutations, such as deletions in exon 19 and point mutations in exon 21, are considered the most reliable predictive factors of outcome after treatment of non-small cell lung cancer (NSCLC) with EGFR tyrosine kinase inhibitors (EGFR-TKIs). Gefitinib was approved as a first-line therapy for NSCLC based on the

\footnotetext{
* Correspondence: jclee@amc.seoul.kr; kyleemd@kuh.ac.kr

${ }^{\dagger}$ Equal contributors

${ }^{6}$ Department of Oncology, Asan Medical Center, College of Medicine, University of Ulsan, 388-1 Pungnap-2 Dong, Songpa-Gu, Seoul 138-736, Korea

${ }^{12}$ Department of Internal Medicine, Konkuk University Medical Center, 4-12 Hwayang-dong, Gwangjin-gu, Seoul 143-729, Korea

Full list of author information is available at the end of the article
}

results of a phase III landmark study, the Iressa Pan-Asia Study (IPASS), which showed that gefitinib conferred a survival benefit in EGFR mutation-positive patients over conventional chemotherapy [1]. The trial clearly showed that the selection of EGFR-TKIs should be based on molecular markers, not on clinical characteristics. Since then, given that many patients cannot receive second-line therapy after first-line failure because of their generally deteriorating condition, EGFR mutation testing is requested more frequently at the time of diagnosis for patients with adenocarcinoma. Indeed, a European workshop on EGFR mutation testing in NSCLC recommended testing at diagnosis, or at relapse, whenever possible, although no gold standard testing method was chosen [2].

\section{Biomed Central}


Despite their importance in clinical practice, there is often too little tissue available to examine EGFR status as most are obtained by small needle biopsy or extracted from body fluids rather than via a more aggressive surgical approach. Many investigators have tried to solve this problem, leading to the development of more sensitive techniques to detect EGFR mutations, such as the scorpion-amplified refractory mutation system (SARMS) and the peptide nucleic acid (PNA)-mediated polymerase chain reaction (PCR) clamping method [3-18]. In addition, it is suggested that the plasma of cancer patients contains circulating free DNA (cfDNA) originating from necrotic tumor cells sloughed from the tumor mass or from circulating tumor cells [19-21]. Attempts to detect EGFR mutations in cfDNA using these sensitive techniques are currently in progress. If proven feasible and reliable, the cfDNA test may have broad clinical applications because it is non-invasive, convenient and can be performed repeatedly. In addition, the test could help diagnose lung cancer in cases when an adequate tissue sample is difficult to obtain. Over the past several years, many reports have shown promising results and have supported the feasibility of the test [22-33]. However, the optimal methodology for mutation detection from cfDNA and the possibility for the replacement of tumor tissue to blood sample still need to be confirmed.

In the present study, we examined the status of EGFR mutations in cfDNA isolated from plasma samples by a PNA-mediated PCR clamping method (PNA test) to determine the utility of plasma as a surrogate tissue for EGFR mutation analysis.

\section{Methods}

\section{Patients}

The prospective multicenter study was conducted to analyze EGFR mutations in plasma samples. Sixty patients with advanced NSCLC were recruited from 11 hospitals of the Korean Molecular Lung Cancer Group (KMLCG) between May 2010 and March 2011. All participants had histological or cytological confirmation of advanced NSCLC and showed a partial response to gefitinib as a second-line therapy without regard to the EGFR mutation status. Written informed consents for the use of their blood were obtained from all patients. The study protocol was approved by the Ethical Review Committee of 11 institutions (Korea Cancer Center Hospital, Korea University Guro Hospital, Daegu Catholic University Medical Center, Pusan National University Hospital, Inje University Busan Paik Hospital, Asan Medical Center, Wonkwang University Hospital, Chonnam National University Hwasun Hospital, Chonbuk National University Hospital, Chungnam National University Hospital, Hallym University Medical Center, Konkuk University Medical Center).

\section{Plasma sample collection and DNA extraction}

Whole blood specimens from patients were collected in ethylenediaminetetraacetic acid tubes before and 2 months after the initiation of gefitinib administration and centrifuged at $3000 \mathrm{rpm}$ for 5 minutes. The supernatants were collected and centrifuged at $3000 \mathrm{rpm}$ for 5 minutes. The final supernatants were transferred to Eppendorf tubes and stored at $-70^{\circ} \mathrm{C}$ until DNA extraction. DNA was extracted from 1-2 $\mathrm{ml}$ of supernatant with a DNeasy blood kit (Qiagen) according to the manufacturer's instructions. The final elution volume for DNA extraction was $60 \mu \mathrm{l}$ and the amount of plasma DNA used for mutation testing was $30 \mathrm{ng}$.

\section{PNA-mediated real-time PCR clamping method to detect deletions in EGFR exon 19 and L858R point mutations in EGFR exon 21}

Plasma DNA was analyzed using the PNAClamp ${ }^{\text {TM }}$ EGFR Mutation Detection kit (PANAGENE, Inc., Daejeon, Korea) as described in a previous retrospective study [34]. All reactions were conducted in a $20-\mu$ l volume using template DNA, primers and PNA probe set, and SYBR Green PCR master mix. All reagents were included in the kit. Real-time PCR reactions were performed using a CFX 96 instrument (Bio-Rad, USA). PCR cycling commenced with a $5 \mathrm{~min}$ hold at $94^{\circ} \mathrm{C}$ followed by 40 cycles at $94^{\circ} \mathrm{C}$ for $30 \mathrm{~s}, 70^{\circ} \mathrm{C}$ for $20 \mathrm{~s}, 63^{\circ} \mathrm{C}$ for $30 \mathrm{~s}$, and $72^{\circ} \mathrm{C}$ for $30 \mathrm{~s}$. Two EGFR mutation types were detected using PNA-mediated real-time PCR. The efficiency of PCR clamping was determined by measuring the cycle threshold $(\mathrm{Ct})$ value. $\mathrm{Ct}$ values for the control and mutation assays were obtained by observing the SYBR Green amplification plots. The delta $C t(\Delta C t)$ value was calculated (control $\mathrm{Ct}$ - sample $\mathrm{Ct}$ ), ensuring that the sample and control $\mathrm{Ct}$ values were from the test and wildtype control samples. The cut-off $\Delta \mathrm{Ct}$ was defined as 2 for both the G746_A750 deletion and the L858R point mutation.

\section{Tumor mutation data}

At time of blood collection, we reviewed the EGFR mutation status in patient matched tumor tissue. By the direct sequencing used in routine practice at each institution to established EGFR mutation status in tumor tissue, forty tumor specimens were analyzed for EGFR mutations before gefitinib.

\section{Statistical analyses}

The relationship between EGFR mutations and demographic and clinical features, including age, gender, histological type, performance status (PS), smoking status, TNM stage and response to gefitinib, was analyzed using Pearson's chi-square test or Fisher's exact test. Two-sided P values $<0.05$ were considered statistically 
significant. All analyses were performed using SPSS version 17.0 (SPSS Inc., Chicago, IL, USA).

\section{Results}

\section{Patient characteristics}

The clinical characteristics of the 60 patients are shown in Table 1 . The median age was 62.5 years (range: $38-84$ years). Thirty-nine $(65.0 \%)$ of the patients were female and 21 (35.0\%) were male. Forty-three patients (71.7\%) were nonsmokers. Fifty patients (83.3\%) had good PS. The most common histological subtype was adenocarcinoma (53 patients, $88.3 \%$ ) and the majority of patients (88.3\%) had stage IV disease. As aforementioned, all the patients received secondline gefitinib treatment and showed partial response.

\section{Detection of EGFR mutations in plasma}

EGFR mutations were identified in 10/60 (16.7\%) plasma samples by PNA testing. Of these, seven (70.0\%) were

\section{Table 1 Clinical characteristics of 60 patients}

\begin{tabular}{|c|c|}
\hline & Total $(n=60)$ \\
\hline \multicolumn{2}{|l|}{ Age } \\
\hline Median, years & 62.5 \\
\hline Range & $38-84$ \\
\hline \multicolumn{2}{|l|}{ Gender } \\
\hline Female & 39 (65.0\%) \\
\hline Male & $21(35.0 \%)$ \\
\hline \multicolumn{2}{|l|}{ Smoking history } \\
\hline Nonsmoker & $43(71.7 \%)$ \\
\hline Ex-smoker & $11(18.3 \%)$ \\
\hline Current smoker & $6(10.0 \%)$ \\
\hline \multicolumn{2}{|l|}{ WHO Performance status } \\
\hline Normal activity & $23(38.3 \%)$ \\
\hline Restricted activity & $27(45.0 \%)$ \\
\hline In bed $<50 \%$ of the time & $9(15.0 \%)$ \\
\hline In bed $>50 \%$ of the time & $1(1.7 \%)$ \\
\hline \multicolumn{2}{|l|}{ Tumor histology } \\
\hline ADC & $53(88.3 \%)$ \\
\hline SQC & $3(5.0 \%)$ \\
\hline LCC & $1(1.7 \%)$ \\
\hline NSCLC NOS & $2(3.3 \%)$ \\
\hline Others & $1(1.7 \%)$ \\
\hline \multicolumn{2}{|l|}{ Stage } \\
\hline$\| \mathrm{A}$ & $3(5.0 \%)$ \\
\hline$\| I \mathrm{~B}$ & $4(6.7 \%)$ \\
\hline IV & $53(88.3 \%)$ \\
\hline
\end{tabular}

Abbreviations: $A D C$ adenocarcinoma, SQC squamous cell carcinoma, $L C C$ large cell carcinoma, NSCLC NOS non-small cell lung cancer not otherwise specified.
Table 2 EGFR mutational status in plasma DNA samples

\begin{tabular}{lll}
\hline & Positive & Negative \\
& $\begin{array}{l}\text { EGFR mutation } \\
(\mathbf{n = 1 0 )}\end{array}$ & $\begin{array}{l}\text { EGFR mutation } \\
(\mathbf{n}=\mathbf{5 0})\end{array}$ \\
\hline Exon 19 deletion & $7(70.0 \%)$ & - \\
Exon 21 point mutation & $3(30.0 \%)$ & - \\
\hline
\end{tabular}

in-frame deletions within exon 19 and three (30.0\%) were arginine-to-leucine substitutions at amino acid 858 in exon 21 (L858R) (Table 2). After 2 months of treatment, a repetition of the test in EGFR mutation-positive patients showed that none had EGFR mutations.

\section{Comparison of matched tumor sequencing and plasma EGFR mutations}

To evaluate the accuracy of the results of the PNA test, we compared plasma EGFR mutations with tumor sequencing in 40 paired donor-matched plasma and tumor tissue specimens. EGFR mutations were detected in the plasma samples of six (15.0\%) patients, including four deletions in exon 19 and two point mutations in exon 21 . In the donor-matched tumor tissues, 35 mutations were detected $(87.5 \%)$ by using direct sequencing, including 18 in exon 19 and 17 in exon 21 . Of the patients with plasma EGFR mutations, mutations of identical exon site were detected in the matched tumor tissues (Table 3).

\section{Correlation between EGFR mutation status assessed by PNA-mediated real-time PCR clamping and clinical features}

EGFR mutations in plasma were detected more frequently in females $(17.9 \%$ vs. $14.3 \%$ in male), nonsmokers (18.6\% vs. $11.8 \%$ in current/former smokers) and patients with stage IIIB disease $(25.0 \%$ vs. $17.0 \%$ in stage IV). In addition, the overall mutation detection rate at the institute at which the central laboratory was located, and where sample processing did not require shipment, was relatively higher than that at the other institutes ( $23.8 \%$ vs. $12.8 \%)$; however, there were no statistically significant differences between the number of patients with EGFR mutations in plasma and those without (Table 4).

Table 3 EGFR mutational status in the paired specimens of plasma and tumor tissue

\begin{tabular}{llll}
\hline $\mathbf{N}=\mathbf{4 0}$ & & \multicolumn{2}{l}{ Plasma EGFR mutation } \\
\cline { 3 - 4 } & & Positive & Negative \\
\hline Tissue EGFR mutation & positive & 6 & 29 \\
& negative & 0 & 5 \\
\hline
\end{tabular}


Table 4 Different characteristics according plasma EGFR mutational status

\begin{tabular}{|c|c|c|c|}
\hline & $\begin{array}{l}\text { Patients with } \\
\text { plasma EGFR } \\
\text { mutation } \\
(n=10)\end{array}$ & $\begin{array}{l}\text { Patients without } \\
\text { plasma EGFR } \\
\text { mutation } \\
(n=50)\end{array}$ & $\begin{array}{c}P \\
\text { value }\end{array}$ \\
\hline \multicolumn{4}{|l|}{ Age } \\
\hline Median, years & 60.5 & 63.0 & 0.76 \\
\hline Range & $51-76$ & $38-84$ & \\
\hline \multicolumn{4}{|l|}{ Gender } \\
\hline Female & $7(70.0 \%)$ & $32(64.0 \%)$ & 1.00 \\
\hline Male & $3(30.0 \%)$ & $18(36.0 \%)$ & \\
\hline \multicolumn{4}{|l|}{ Smoking history } \\
\hline Nonsmoker & $8(80.0 \%)$ & $35(70.0 \%)$ & 0.67 \\
\hline Ex-smoker & $1(10.0 \%)$ & $10(20.0 \%)$ & \\
\hline Current smoker & $1(10.0 \%)$ & $5(10.0 \%)$ & \\
\hline \multicolumn{4}{|l|}{ WHO Performance status } \\
\hline Normal activity & $4(40.0 \%)$ & 19 (38.0\%) & 0.94 \\
\hline Restricted activity & $4(40.0 \%)$ & $23(46.0 \%)$ & \\
\hline In bed $<50 \%$ of the time & $2(20.0 \%)$ & $7(14.0 \%)$ & \\
\hline In bed $>50 \%$ of the time & - & $1(2.0 \%)$ & \\
\hline \multicolumn{4}{|l|}{ Tumor histology } \\
\hline ADC & $9(90.0 \%)$ & $44(88.0 \%)$ & 0.83 \\
\hline SQC & - & $3(6.0 \%)$ & \\
\hline LCC & - & $1(2.0 \%)$ & \\
\hline NSCLC NOS & $1(10.0 \%)$ & $1(2.0 \%)$ & \\
\hline Others & - & $1(2.0 \%)$ & \\
\hline \multicolumn{4}{|l|}{ Stage } \\
\hline$\| \mathrm{A}$ & - & $3(6.0 \%)$ & 0.64 \\
\hline 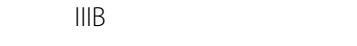 & $1(10.0 \%)$ & $3(6.0 \%)$ & \\
\hline IV & $9(90.0 \%)$ & $44(88.0 \%)$ & \\
\hline \multicolumn{4}{|l|}{ Central labotory } \\
\hline on-site & $5(50.0 \%)$ & $16(32.0 \%)$ & 0.30 \\
\hline off-site & $5(50.0 \%)$ & $34(68.0 \%)$ & \\
\hline
\end{tabular}

Abbreviations: $A D C$ adenocarcinoma, SQC squamous cell carcinoma $L C C$ large cell carcinoma, NSCLC NOS non-small cell lung cancer not otherwise specified.

\section{Discussion}

Direct sequencing of amplified DNA products using Sanger's method is the most popular test for detecting EGFR mutations. However, this method is limited by low sensitivity (meaning that the mutant DNA must represent greater than $25 \%$ of the total DNA), and requires multiple steps to be performed over several days [15]. Furthermore, in patients with advanced NSCLC, tumor tissue is not always available for EGFR mutation testing either because only small amounts of tissue are collected or because the tissues collected have very low, or non-existent, tumor content . For these reasons, new techniques are needed for more sensitive and rapid detection. Several new techniques, including SARMS, Taqman PCR, and denaturing high-performance liquid chromatography (dHPLC) have been introduced, although none have been adopted as a standard method for detecting EGFR mutations [4,5,9-11,13,14,16,22-24,26-28,30-33].

Peptide nucleic acid (PNA) is an artificial polymer with the properties of both nucleic acids and proteins. PNA can bind tightly to complementary sequences in DNA because of a lack of electrostatic repulsion. Therefore, when a PNA oligomer, designed to detect an EGFR mutation and to bind to the antisense strand of the wildtype EGFR gene, is used for real-time PCR, amplification is rapid and sensitive and displays similar sensitivity to SARMS. Several studies using this novel method have been published $[8,17,34,35]$, however, to our knowledge, there are no reports showing detection of EGFR mutations in cfDNA extracted from the plasma of NSCLC patients using PNA-mediated real time PCR clamping.

In the present study, the detection rate of EGFR mutations in cfDNA was $16.1 \%$. This is somewhat lower than that reported previously, which ranges from $20 \%$ to $73 \%$ (Table 5) [16,24,26-28,32]. Mutation detection rates can differ between subjects and between methods. Around $50-60 \%$ of Asian patients and $20-30 \%$ of Western patients with adenocarcinomas are expected to carry activating EGFR mutations, while a negligible proportion of patients with other lung cancer histology are expected to carry such mutations. Therefore, the EGFR mutation detection rate can be estimated from the clinical and demographic parameters, including race and histology, of the study subjects. If we assume that $50 \%$ of Asian adenocarcinoma patients carry EGFR mutations, the expected detection rate in an Asian study population comprising $80 \%$ adenocarcinoma patients should be $40 \%$. In this context, the results of several previous studies suggesting that the EGFR mutation test in cfDNA might be equivalent to that in tissue exceed the expected rate of EGFR positivity. Hence, it is difficult to accept these although the tests used in those studies are highly sensitive and always performed with the utmost precision. In addition, other reports published detection rates around $20 \%$ [26,27], which is similar to our report, and still EGFR mutation testing in cfDNA has not been introduced in clinical practice in spite of such promising results over several years. Therefore, more data are required to evaluate the suitability of the cfDNA test and assess whether it can replace the traditional tumor tissue test.

The T790M mutation was not detected in any of the samples that were positive for activating EGFR mutations, although one report showed that low levels of T790M were detected in pretreatment tumor samples from 10/26 patients (38\%) [24]. The detection rate of T790M seems to be 
Table 5 Previous reports on EGFR mutation test from circulating free DNA

\begin{tabular}{|c|c|c|c|c|c|}
\hline Year & Authors & Subjects & DNA concentration & Mutation test & Detection rate \\
\hline \multirow[t]{5}{*}{2006} & \multirow[t]{5}{*}{ Kimura H, et al. [16] } & Asian & \multirow{5}{*}{$\begin{array}{l}70 \mathrm{ng} / \mathrm{mL} \\
\text { (range, } 0-1720 \mathrm{ng} / \mathrm{mL} \text { ) }\end{array}$} & \multirow[t]{5}{*}{ SARMS } & \multirow[t]{5}{*}{$48.1 \%(13 / 27)$} \\
\hline & & Female : $37 \%$ & & & \\
\hline & & Nonsmoker : N/A & & & \\
\hline & & $A D C: 85 \%$ & & & \\
\hline & & ORR : $33 \%$ & & & \\
\hline \multirow[t]{2}{*}{2008} & \multirow[t]{2}{*}{ Maheswaran S, et al. [24] } & Western & \multirow[t]{2}{*}{ N/A } & \multirow[t]{2}{*}{ SARMS } & \multirow[t]{2}{*}{$39 \%(7 / 18)$} \\
\hline & & EGFR mutant patients & & & \\
\hline \multirow[t]{4}{*}{2009} & \multirow[t]{4}{*}{ He C, et al. [29] } & Asian & \multirow[t]{4}{*}{ N/A } & \multirow[t]{4}{*}{ Mutant-enriched PCR } & \multirow[t]{4}{*}{$49.3 \%(66 / 134)$} \\
\hline & & Female : 37\% & & & \\
\hline & & Nonsmoker : 53\% & & & \\
\hline & & ADC : $75 \%$ & & & \\
\hline \multirow[t]{5}{*}{2009} & \multirow[t]{5}{*}{ Bai H, et al. [28] } & Asian & \multirow[t]{5}{*}{ N/A } & \multirow[t]{5}{*}{ dHPLC } & \multirow[t]{5}{*}{$34.3 \%(79 / 230)$} \\
\hline & & Female : 46\% & & & \\
\hline & & Nonsmoker : 55\% & & & \\
\hline & & ADC : 74\% & & & \\
\hline & & ORR : 36\% (37/102) & & & \\
\hline \multirow[t]{4}{*}{2009} & \multirow[t]{4}{*}{ Mack PC, et al. [26] } & Western/Asian : 96/4\% & \multirow{4}{*}{$\begin{array}{l}2.3 \mathrm{ng} / \mu \mathrm{L} \\
\text { (range, } 1-9 \mathrm{ng} / \mu \mathrm{L} \text { ) }\end{array}$} & \multirow[t]{4}{*}{ SARMS } & \multirow[t]{4}{*}{$20 \%(10 / 49)$} \\
\hline & & Female : $56 \%$ & & & \\
\hline & & Nonsmoker : 53\% & & & \\
\hline & & $A D C: 67 \%$ & & & \\
\hline \multirow[t]{5}{*}{2009} & \multirow[t]{5}{*}{ Kuang Y, et al. [25] } & Western & \multirow{5}{*}{$\begin{array}{l}52.3 \mathrm{ng} / \mu \mathrm{L} \text { (range, } \\
10-163 \mathrm{ng} / \mu \mathrm{L} \text { ) }\end{array}$} & SARMS and WAVE/Surveyor & \multirow[t]{5}{*}{$54 \%(29 / 54)$} \\
\hline & & Female : $81.5 \%$ & & Whole genome amplification & \\
\hline & & Nonsmoker : N/A & & & \\
\hline & & $A D C: N / A$ & & & \\
\hline & & ORR : $56 \%$ & & & \\
\hline 2010 & Brevet $M$, et al. [31] & Western & N/A & Mass spectrometry genotyping & $23.2 \%(10 / 31)$ \\
\hline & & Female : 52\% & & $\begin{array}{l}\text { assay (Sequenom) and mutant- } \\
\text { enriched PCR }\end{array}$ & \\
\hline & & Nonsmoker : 45\% & & Whole genome amplification & \\
\hline & & ADC : 97\% & & & \\
\hline 2010 & Jian G, et al. [27] & Asian & N/A & Taqman PCR & $23.2 \%(13 / 56)$ \\
\hline & & Female : 46\% & & & \\
\hline & & Nonsmoker : 58\% & & & \\
\hline & & ADC : 78\% & & & \\
\hline
\end{tabular}


Table 5 Previous reports on EGFR mutation test from circulating free DNA (Continued)

\begin{tabular}{|c|c|c|c|c|c|}
\hline & & ORR : $30 \%$ & & & \\
\hline \multirow[t]{4}{*}{2011} & \multirow[t]{4}{*}{ Jiang B, et al. [30] } & Asian & \multirow{4}{*}{$\begin{array}{l}\text { Minimum } 4 \mathrm{ng} / \mathrm{\mu L} \\
\text { (range, } 11-66 \mathrm{ng} / \mu \mathrm{L} \text { ) }\end{array}$} & \multirow[t]{4}{*}{ Mutant-enriched PCR } & \multirow[t]{4}{*}{$31 \%(18 / 58)$} \\
\hline & & Female : $31 \%$ & & & \\
\hline & & Nonsmoker : 38\% & & & \\
\hline & & ADC : $72 \%$ & & & \\
\hline \multirow[t]{2}{*}{2011} & \multirow[t]{2}{*}{ Taniguchi K, et al. [32] } & Asian & \multirow[t]{2}{*}{ N/A } & \multirow[t]{2}{*}{ BEAMing } & \multirow[t]{2}{*}{$72.7 \%(32 / 44)$} \\
\hline & & EGFR mutant patients & & & \\
\hline \multirow[t]{5}{*}{ This study } & \multirow[t]{5}{*}{ Kim HR, et al. } & Asian & \multirow[t]{5}{*}{$8.6 \mathrm{ng} / \mu \mathrm{L}$} & \multirow[t]{5}{*}{ PNA-based PCR clamping } & \multirow[t]{5}{*}{$16.7 \%(10 / 60)$} \\
\hline & & Female : $65 \%$ & & & \\
\hline & & Nonsmoker : 2\% & & & \\
\hline & & ADC : $88 \%$ & & & \\
\hline & & ORR : $100 \%$ & & & \\
\hline
\end{tabular}

Abbreviations: $A D C$ adenocarcinoma, SARMS scorpion-amplified refractory mutation system, $P C R$ polymerase chain reaction, dHPLC denaturing high-performance liquid chromatography, BEAMing beads, emulsion, amplification, and magnetics, PNA peptide nucleic acid. 
closely associated with the sensitivity of the EGFR mutation test. A study using the BEAMing (beads, emulsion, amplification, and magnetics) method showed that the proportion of T790M within activating mutations ranged from 13.3$94.0 \%$, and calculated that the T790M peak within the mutant allele fraction would range from $0.1-1 \%$ in cfDNA [32]. Therefore, even with a higher sensitivity permitting detection of $1 \%$ mutant DNA, as is reached with SARMS and PNA-based PCR clamping, detection of the T790M mutation in cfDNA remains difficult. This suggests that circulating tumor cells (CTC) would be a better alternative source material in which to detect the T790M mutation, and for predicting progression-free survival.

None of the EGFR mutations initially detected in cfDNA before treatment were detected 2 months after EGFR-TKI therapy and partial response. Since the initial tumor size and stage did not correlate with the detection rate, this result suggests that the amount of actively proliferating tumor cells, rather than the tumor burden, could affect the amount of circulating tumor DNA. Accordingly, in a previous CTC study, a 50\% decline in CTCs within 1 week was noted in one patient, with the nadir reached 3 months after treatment, while the number of CTCs increased at the time of clinical progression and declined again when the tumor responded to subsequent chemotherapy [24]. It was also evident that, although CTC detection was not associated with initial tumor burden, there was a close concordance between tumor response and the number of CTCs during treatment.

Finally, our results suggest that better processing of plasma samples and on-site testing without necessity of sample delivery can improve detection rate.

In summary, our results show that, although detection of EGFR mutations in cfDNA is possible in some patients, more data are required to evaluate clinical applicability. Technical advances in sensitivity, stability and standardization are also needed, as well as adequate sample processing.

\section{Competing interests}

The authors had no competing interest to declare.

\section{Authors' contributions}

YCK, SHJ, KYL and JCL contributed to study conception and design. SYL, $\mathrm{DSH}, \mathrm{MKL}, \mathrm{HKL}, \mathrm{CMC}, \mathrm{SHY}, \mathrm{YCK}$ and SYK were involved in acquisition and analysis of data, HRK and JCL wrote the manuscript. KYL confirmed the final draft. All authors read and approved the final manuscript.

\section{Acknowledgements}

This study was supported by a grant from the Korean association for the study of lung cancer (KASLC-1001).

\section{Author details}

'Korea Cancer Center Hospital, Seoul, Korea. ${ }^{2}$ Korea University Guro Hospital, Seoul, South Korea. ${ }^{3}$ Daegu Catholic University Medical Center, Daegu, Korea. ${ }^{4}$ Pusan National University Hospital, Busan, Korea. ${ }^{5}$ Inje University Busan Paik Hospital, Busan, South Korea. ${ }^{6}$ Department of Oncology, Asan Medical Center, College of Medicine, University of Ulsan, 388-1 Pungnap-2 Dong, Songpa-Gu, Seoul 138-736, Korea. 'Wonkwang University Hospital, Iksan,
Korea. ${ }^{8}$ Chonnam National University Hwasun Hospital, Hwasun-Gun, Korea. ${ }^{9}$ Chonbuk National University Hospital, Chonju, Korea. ${ }^{10}$ Chungnam National University Hospital, Daejeon, Korea. ${ }^{11}$ Hallym University Sacred Heart Hospital, Anyang, Korea. ${ }^{12}$ Department of Internal Medicine, Konkuk University Medical Center, 4-12 Hwayang-dong, Gwangjin-gu, Seoul 143-729, Korea.

Received: 15 June 2013 Accepted: 8 August 2013

Published: 9 August 2013

\section{References}

1. Mok TS, Wu YL, Thongprasert S, Yang CH, Chu DT, Saijo N, Sunpaweravong $P$, Han B, Margono B, Ichinose $Y$, Nishiwaki $Y$, Ohe $Y$, Yang JJ, Chewaskulyong $B$, Jiang $H$, Duffield $E L$, Watkins $C L$, Armour AA, Fukuoka M: Gefitinib or carboplatin-paclitaxel in pulmonary adenocarcinoma. N Engl J Med 2009, 361:947-957.

2. Pirker R, Herth FJ, Kerr KM, Filipits M, Taron M, Gandara D, Hirsch FR, Grunenwald D, Popper H, Smit E, Dietel M, Marchetti A, Manegold C, Schirmacher P, Thomas M, Rosell R, Cappuzzo F, Stahel R: European EGFR Workshop Group. Consensus for EGFR mutation testing in non-small cell lung cancer: results from a European workshop. J Thorac Oncol 2010, 5:1706-1713.

3. Marchetti A, Martella C, Felicioni L, Barassi F, Salvatore S, Chella A, Camplese PP, larussi T, Mucilli F, Mezzetti A, Cuccurullo F, Sacco R, Buttitta F: EGFR mutations in non-small-cell lung cancer: analysis of a large series of cases and development of a rapid and sensitive method for diagnostic screening with potential implications on pharmacologic treatment. J Clin Oncol 2005, 23:857-865.

4. Endo K, Konishi A, Sasaki H, Takada M, Tanaka H, Okumura M, Kawahara M, Sugiura H, Kuwabara Y, Fukai I, Matsumura A, Yano M, Kobayashi Y, Mizuno K, Haneda H, Suzuki E, luchi K, Fujii Y: Epidermal growth factor receptor gene mutation in non-small cell lung cancer using highly sensitive and fast TaqMan PCR assay. Lung Cancer 2005, 50:375-384.

5. Zhou C, Ni J, Zhao Y, Su B: Rapid detection of epidermal growth factor receptor mutations in non-small cell lung cancer using real-time polymerase chain reaction with TaqMan-MGB probes. Cancer J 2006 12:33-39.

6. Yatabe $Y$, Hida T, Horio Y, Kosaka T, Takahashi T, Mitsudomi T: A rapid, sensitive assay to detect EGFR mutation in small biopsy specimens from lung cancer. J Mol Diagn 2006, 8:335-341.

7. Pan Q, Pao W, Ladanyi M: Rapid polymerase chain reaction-based detection of epidermal growth factor receptor gene mutations in lung adenocarcinomas. J Mol Diagn 2005, 7:396-403.

8. Tanaka T, Nagai Y, Miyazawa H, Koyama N, Matsuoka S, Sutani A, Huqun, Udagawa K, Murayama Y, Nagata M, Shimizu Y, Ikebuchi K, Kanazawa M Kobayashi K, Hagiwara K: Reliability of the peptide nucleic acid-locked nucleic acid polymerase chain reaction clamp-based test for epidermal growth factor receptor mutations integrated into the clinical practice for non-small cell lung cancers. Cancer Sci 2007, 98:246-252.

9. Janne PA, Borras AM, Kuang Y, Rogers AM, Joshi VA, Liyanage $H$, Lindeman N, Lee JC, Halmos B, Maher EA, Distel RJ, Meyerson M, Johnson BE: A rapid and sensitive enzymatic method for epidermal growth factor receptor mutation screening. Clin Cancer Res 2006, 12:751-758.

10. Chin TM, Anuar D, Soo R, Salto-Tellez M, Li WQ, Ahmad B, Lee SC, Goh BC, Kawakami K, Segal A, lacopetta B, Soong R: Detection of epidermal growth factor receptor variations by partially denaturing HPLC. Clin Chem 2007, 53:62-70.

11. Cohen V, Agulnik JS, Jarry J, Batist G, Small D, Kreisman H, Tejada NA, Miller WH Jr, Chong G: Evaluation of denaturing high-performance liquid chromatography as a rapid detection method for identification of epidermal growth factor receptor mutations in nonsmall-cell lung cancer. Cancer 2006, 107:2858-2865.

12. Thomas RK, Nickerson E, Simons JF, Janne PA, Tengs T, Yuza Y, Garraway LA, LaFramboise T, Lee JC, Shah K, O'Neill K, Sasaki H, Lindeman N, Wong KK Borras AM, Gutmann EJ, Dragnev KH, DeBiasi R, Chen TH, Glatt KA, Greulich H, Desany B, Lubeski CK, Brockman W, Alvarez P, Hutchison SK, Leamon JH, Ronan MT, Turenchalk GS, Egholm M, Sellers WR, Rothberg JM, Meyerson M: Sensitive mutation detection in heterogeneous cancer specimens by massively parallel picoliter reactor sequencing. Nat Med 2006, 12:852-855.

13. Asano H, Toyooka S, Tokumo M, Ichimura K, Aoe K, Ito S, Tsukuda K, Ouchida M, Aoe M, Katayama H, Hiraki A, Sugi K, Kiura K, Date H, Shimizu N: 
Detection of EGFR gene mutation in lung cancer by mutant-enriched polymerase chain reaction assay. Clin Cancer Res 2006, 12:43-48.

14. Hoshi K, Takakura H, Mitani Y, Tatsumi K, Momiyama N, Ichikawa Y, Togo S, Miyagi T, Kawai Y, Kogo Y, Kikuchi T, Kato C, Arakawa T, Uno S, Cizdziel PE, Lezhava A, Ogawa N, Hayashizaki Y, Shimada H: Rapid detection of epidermal growth factor receptor mutations in lung cancer by the SMart-Amplification Process. Clin Cancer Res 2007, 13:4974-4983.

15. Pao W, Ladanyi M: Epidermal growth factor receptor mutation testing in lung cancer: searching for the ideal method. Clin Cancer Res 2007, 13:4954-4955.

16. Kimura H, Kasahara K, Kawaishi M, Kunitoh H, Tamura T, Holloway B, Nishio $K$ : Detection of epidermal growth factor receptor mutations in serum as a predictor of the response to gefitinib in patients with non-small-cell lung cancer. Clin Cancer Res 2006, 12:3915-3921.

17. Nagai Y, Miyazawa H, Huqun, Tanaka T, Udagawa K, Kato M, Fukuyama S, Yokote A, Kobayashi K, Kanazawa M, Hagiwara K: Genetic heterogeneity of the epidermal growth factor receptor in non-small cell lung cancer cell lines revealed by a rapid and sensitive detection system, the peptide nucleic acidlocked nucleic acid PCR clamp. Cancer Res 2005, 65:7276-7282.

18. John T, Liu G, Tsao MS: Overview of molecular testing in non-small-cell lung cancer: mutational analysis, gene copy number, protein expression and other biomarkers of EGFR for the prediction of response to tyrosine kinase inhibitors. Oncogene 2009, 28(Suppl 1):S14-S23.

19. Stroun M, Maurice P, Vasioukhin V, Lyautey J, Lederrey C, Lefort F, Rossier A, Chen XQ, Anker P: The origin and mechanism of circulating DNA. Ann N Y Acad Sci 2000, 906:161-168.

20. Stroun M, Lyautey J, Lederrey C, Olson-Sand A, Anker P: About the possible origin and mechanism of circulating DNA apoptosis and active DNA release. Clin Chim Acta 2001, 313:139-142.

21. Aung KL, Board RE, Ellison G, Donald E, Ward T, Clack G, Ranson M, Hughes A, Newman W, Dive C: Current status and future potential of somatic mutation testing from circulating free DNA in patients with solid tumours. Hugo J 2010, 4:11-21.

22. Kimura H, Kasahara K, Shibata K, Sone T, Yoshimoto A, Kita T, Ichikawa Y, Waseda Y, Watanabe K, Shiarasaki H, Ishiura Y, Mizuguchi M, Nakatsumi Y, Kashii T, Kobayashi M, Kunitoh $H$, Tamura T, Nishio K, Fujimura M, Nakao S: EGFR mutation of tumor and serum in gefitinib-treated patients with chemotherapy-naive non-small cell lung cancer. J Thorac Oncol 2006, 1:260-267.

23. Kimura H, Suminoe M, Kasahara K, Sone T, Araya T, Tamori S, Koizumi F, Nishio K, Miyamoto K, Fujimura M, Nakao S: Evaluation of epidermal growth factor receptor mutation status in serum DNA as a predictor of response to gefitinib (IRESSA). Br J Cancer 2007, 97:778-784.

24. Maheswaran S, Sequist LV, Nagrath S, Ulkus L, Brannigan B, Collura CV, Inserra E, Diederichs S, lafrate AJ, Bell DW, Digumarthy S, Muzikansky A, Irimia D, Settleman J, Tompkins RG, Lynch TJ, Toner M, Haber DA: Detection of mutations in EGFR in circulating lung-cancer cells. N Engl J Med 2008, 359:366-377.

25. Kuang Y, Rogers A, Yeap BY, Wang L, Makrigiorgos M, Vetrand K, Thiede S, Distel RJ, Jänne PA: Noninvasive detection of EGFR T790M in gefitinib or erlotinib resistant non-small cell lung cancer. Clin Cancer Res 2009, 15:2630-2636.

26. Mack PC, Holland WS, Burich RA, Sangha R, Solis LJ, Li Y, Beckett LA, Lara PN $\mathrm{Jr}$, Davies AM, Gandara DR: EGFR mutations detected in plasma are associated with patient outcomes in erlotinib plus docetaxel-treated non-small cell lung cancer. J Thorac Oncol 2009, 4:1466-1472.

27. Jian G, Songwen Z, Ling Z, Qinfang D, Jie Z, Liang T, Caicun Z: Prediction of epidermal growth factor receptor mutations in the plasma/pleural effusion to efficacy of gefitinib treatment in advanced non-small cell lung cancer. J Cancer Res Clin Oncol 2010, 136:1341-1347.

28. Bai H, Mao L, Wang HS, Zhao J, Yang L, An TT, Wang X, Duan CJ, Wu NM, Guo ZQ, Liu YX, Liu HN, Wang YY, Wang J: Epidermal growth factor receptor mutations in plasma DNA samples predict tumor response in Chinese patients with stages IIIB to IV non-small-cell lung cancer. J Clin Oncol 2009, 27:2653-2659.

29. He C, Liu M, Zhou C, Zhang J, Ouyang M, Zhong N, Xu J: Detection of epidermal growth factor receptor mutations in plasma by mutantenriched PCR assay for prediction of the response to gefitinib in patients with non-small-cell lung cancer. Int J Cancer 2009, 125:2393-2399.

30. Jiang B, Liu F, Yang L, Zhang W, Yuan H, Wang J, Huang G: Serum detection of epidermal growth factor receptor gene mutations using mutant-enriched sequencing in Chinese patients with advanced nonsmall cell lung cancer. J Int Med Res 2011, 39:1392-1401.
31. Brevet M, Johnson ML, Azzoli CG, Ladanyi M: Detection of EGFR mutations in plasma DNA from lung cancer patients by mass spectrometry genotyping is predictive of tumor EGFR status and response to EGFR inhibitors. Lung Cancer 2011, 73:96-102.

32. Taniguchi K, Uchida J, Nishino K, Kumagai T, Okuyama T, Okami J, Higashiyama M, Kodama K, Imamura F, Kato K: Quantitative detection of EGFR mutations in circulating tumor DNA derived from lung adenocarcinomas. Clin Cancer Res 2011, 17:7808-7815.

33. Nakamura T, Sueoka-Aragane N, Iwanaga K, Sato A, Komiya K, Abe T, Ureshino N, Hayashi S, Hosomi T, Hirai M, Sueoka E, Kimura S: A noninvasive system for monitoring resistance to epidermal growth factor receptor tyrosine kinase inhibitors with plasma DNA. J Thorac Oncol 2011, 6:1639-1648.

34. Kim HJ, Lee KY, Kim YC, Kim KS, Lee SY, Jang TW, Lee MK, Shin KC, Lee GH, Lee JC, Lee JE, Kim SY: Detection and comparison of peptide nucleic acidmediated real-time polymerase chain reaction clamping and direct gene sequencing for epidermal growth factor receptor mutations in patients with non-small cell lung cancer. Lung Cancer 2011, 75:321-325.

35. Han HS, Lim SN, An JY, Lee KM, Choe KH, Lee KH, Kim ST, Son SM, Choi SY, Lee $H C$, Lee OJ: Detection of EGFR mutation status in lung adenocarcinoma specimens with different proportions of tumor cells using two methods of differential sensitivity. J Thorac Oncol 2012, 7:355-364.

doi:10.1186/1756-9966-32-50

Cite this article as: Kim et al: Detection of EGFR mutations in circulating free DNA by PNA-mediated PCR clamping. Journal of Experimental \& Clinical Cancer Research 2013 32:50.

\section{Submit your next manuscript to BioMed Central and take full advantage of:}

- Convenient online submission

- Thorough peer review

- No space constraints or color figure charges

- Immediate publication on acceptance

- Inclusion in PubMed, CAS, Scopus and Google Scholar

- Research which is freely available for redistribution 